\title{
CONTENTS OF VOLUME I
}

PrEFACE PAge

List of Illustrations . . . . . . . . . . . . . . . . . . . . . . . xïi

Note on Terminology . . . . . . . . . . . . . . . . . . . xvii

\section{PART I \\ EARLY CHRISTIAN SCULPTURE}

\section{CHAPTER I}

Early Christian Sculpture.

I. Introduction . . . . . . . . . . . . . . . . . . . . . . . . . 3

2. Sculpture, Other than Byzantine, Until the Seventh Century . . . . 4

Syria . . . . . . . . . . . . . . . . . . 5

Asia Minor . . . . . . . . . . . . . . . . . . . . 5

Egypt .................. 6

Rome . . . . . . . . . . . . . . . . . . 7

Ravenna . . . . . . . . . . . . . . . . 9

Christian Sarcophagi in Other Parts of the Western Empire . . . Io

3. Byzantine Sculpture . . . . . . . . . . . . . . . . . 10

The First Golden Age . . . . . . . . . . . . . . . . . . . Io

The Second Golden Age . . . . . . . . . . . . . . . . . . I3

The Byzantine Renaissance of the Fourteenth Century . . . . . $\quad$ I6

The Influence of Byzantine Art in Europe . . . . . . . . . . 16

4. The Age of Barbarism . . . . . . . . . . . . . . . . . . . . . I6

5. The Carolingian Renaissance . . . . . . . . . . . . . . I8

PART II

THE MIDDLE AGES

CHAPTER II

INTRODUCTION

Romanesque Sculpture.

\section{CHAPTER III}

I. General Character of Romanesque Sculpture . . . . . . . . . . 30

2. France. . . . . . . . . . . . . . . . . . . 34

Languedoc . . . . . . . . . . . . . . 34

Burgundy . . . . . . . . . . . . . . . . . 36

Provence . . . . . . . . . . . . . . . . . 37

Other Schools . . . . . . . . . . . . . $3^{8}$ 
3. Spain . . . . . . . . . . . . . . . . . . . . . 39

4. Germany and Related Countries . . . . . . . . . . . . . . . 4 I

5. The Low Countries . . . . . . . . . . . . . . . . . . . . . . 43

6. England . . . . . . . . . . . . . . . . . . . . . 44

7. Italy . . . . . . . . . . . . . . . . . . . . 46

Northern Italy . . . . . . . . . . . . . . . . . . 47

Southern Italy . . . . . . . . . . . . . . . . . . . . . . . 50

Central Italy . . . . . . . . . . . . . . . . . . . 53

\section{CHAPTER IV}

Gothic ScUlptURE. Introduction . . . . . . . . . . . . . . . . 55

Gothic Sculpture. France.

\section{CHAPTER V}

I. The Transition from Romanesque to Gothic . . . . . . . . . . . 62

2. The Thirteenth Century . . . . . . . . . . . . . . . . . 64

3. The Fourteenth Century . . . . . . . . . . . . . . . . . . . . 69

4. The Fifteenth and Sixteenth Centuries. . . . . . . . . . . . . 73

The School of Burgundy . . . . . . . . . . . . . . . 73

The School of Paris . . . . . . . . . . . . . . . . . . . . 76

Franco-Flemish Work Other than Parisian . . . . . . . . . . 77

5. The Détente . . . . . . . . . . . . . . . . 78

\section{CHAPTER VI}

Gothic Sculpture. The Low Countries . . . . . . . . . . . . . . 84

\section{CHAPTER VII}

Gothic Sculpture. Germany and Related Countries.

I. Introduction . . . . . . . . . . . . . . . . . . . . . . 92

2. The Transition from Romanesque to Gothic . . . . . . . . . . . 92

3. The Developed Style of the Thirteenth Century . . . . . . . . . 95

4. The Fourteenth Century . . . . . . . . . . . . . . . . . . . . 99

5. The Fifteenth and Sixteenth Centuries . . . . . . . . . . . . 102

Northern Germany . . . . . . . . . . . . . . . . . . ${ }_{104}$

Southern Germany . . . . . . . . . . . . . . . . . . . . . 105

Franconia ................ . 105

The School of Nuremberg . . . . . . . . . . . . 105

The School of Würzburg . . . . . . . . . . . . . . 108

Swabia . . . . . . . . . . . . . . . 109

Bavaria . . . . . . . . . . . . . . . III

The Tyrol . . . . . . . . . . . . . . . . . . . . III2

The Upper Rhine . . . . . . . . . . . . . . . . . . . . I I 2

The Middle Rhine . . . . . . . . . . . . . . . II3 


\section{CHAPTER VIII}

Gothic Sculpture. England.

r. Introduction . . . . . . . . . . . . . . . . . . . . . . . II5

2. The Thirteenth Century . . . . . . . . . . . . . II6

3. The Fourteenth Century . . . . . . . . . . . . . . . . . II8

4. The Fifteenth and Sixteenth Centuries. . . . . . . . . . . . I23

CHAPTER IX

Gothic Sculpture. Spain and Portugal.

I. Introduction . . . . . . . . . . . . . . . . . . . . . . . . . I 27

2. The Transitional Period . . . . . . . . . . . . . . . . . . . . 127

3. The Thirteenth Century . . . . . . . . . . . . . . . . . . . . I28

4. The Fourteenth Century . . . . . . . . . . . . . . . . . . . I29

5. The Fifteenth and Sixteenth Centuries . . . . . . . . . . . . I3I

6. Portugal . . . . . . . . . . . . . . . . . . I35

Gothic Sculpture. Italy.

CHAPTER $\mathrm{X}$

I. Introduction . . . . . . . . . . . . . . . . . . . . . . . . . 137

2. Nicola d'Apulia and Giovanni Pisano . . . . . . . . . . . . . 137

3. The Followers of Nicola d'Apulia . . . . . . . . . . . . . . . I42

4. The Pisan Style at Florence . . . . . . . . . . . . . . . . . . 143

5. The Pisan Style at Siena and Naples . . . . . . . . . . . . . . I46

6. The Pisan Style in Lombardy . . . . . . . . . . . . . . . . . I48

7. The Pisan Style at Venice . . . . . . . . . . . . . . . . . . . I I49

8. Conclusion ... . . . . . . . . . . . . . I 50

\section{PART III \\ THE RENAISSANCE}

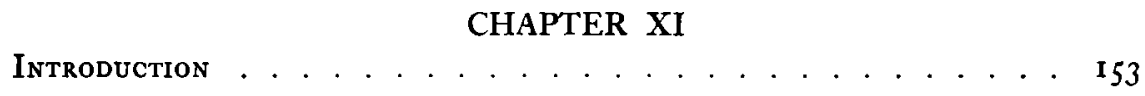

\section{CHAPTER XII}

The Renaissance in Italy. Florentine Sculpture of the Fifteenth Century.

I. Introduction . . . . . . . . . . . . . . . . . . . 157

2. The Three Great Inaugurators of the Quattrocento . . . . . . . . I60

3. The Lesser Sculptors of the First Half of the Quattrocento . . . . . I7I

4. Two Innovators of the First Half of the Quattrocento . . . . . . . I7I

5. The Second Half of the Quattrocento. The Pupils of Donatello . . 175

6. The Second Half of the Quattrocento. The Sentimentalists . . . . . 177

7. The Second Half of the Quattrocento. The Intermediate Group . . 18I

8. The Second Half of the Quattrocento. The Extreme Realists . . . I84 
The Renaissance in Italy. The Sculpture of the Fifteenth Century OUtSide of Florence.

I. Siena . . . . . . . . . . . . . . . . . . . . . . . . . . I88

2. Lombardy . . . . . . . . . . . . . . . . . . . I88

3. Venice . . . . . . . . . . . . . . . . . . . . 195

4. Emilia . . . . . . . . . . . . . . . . . . . . 199

5. Rome . . . . . . . . . . . . . . . . . . 201

6. Southern Italy . . . . . . . . . . . . . . . . . . . . . . . . 204

\section{CHAPTER XIV}

The Renaissance in Italy. The Sixtennth Century.

I. Introduction . . . . . . . . . . . . . . . . . . . . . . 210

2. The Transition . . . . . . . . . . . . . . . . . . . 213

3. Michael Angelo . . . . . . . . . . . . . . . . . . . . . . 216

4. The Colossal Tendency . . . . . . . . . . . . . . . . . . . 223

5. The Tendency to Elegance . . . . . . . . . . . . . . . . . . . 225

6. The Transition to the Baroque . . . . . . . . . . . . . . . 233

\section{CHAPTER XV}

The Renaissance Outside of Italy.
I. France . . . . . . . . . . . . . . . . . . . . . . . . . . . . 237
2. The Low Countries . . . . . . . . . . . . . . . . . . . . . . 244
3. Germany and Related Countries . . . . . . . . . . . . . . . . 248
4. England . . . . . . . . . . . . . . . . . . 259
5. Spain . . . . . . . . . . . . . . . . . . 26I 